\title{
DEFUZZIFIKÁCIÓS MÓDSZEREK ÖSSZEHASONLÍTÁSA LÉGKONDICIONÁLÓ RENDSZEREK ESETÉN
}

\section{COMPARISON OF DEFUZZIFICATION METHODS IN CASE OF AIR CONDITIONING SYSTEMS}

\author{
Koçak, Sinan ${ }^{1}$, Pokorádi László \\ ${ }^{1}$ Óbudai Egyetem Biztonságtudományi Doktori Iskola, doktorandusz, Magyarország \\ 1081 Budapest, Népszínház u. 8.; +36 30 6068233, sinan.kocak@bgk.uni-obuda.hu \\ 2 Óbudai Egyetem Mechatronikai és Jármütechnikai Intézet, egyetemi tanár, Magya- \\ rország 1081 Budapest, Népszínház u. $8 . ; \quad+36 \quad 30 \quad 9194929$ \\ pokoradi.laszlo@bgk.uni-obuda.hu
}

\begin{abstract}
This paper provides the design for air conditioning system and two different defuzzification methods. The air conditioner intelligent system is the control of two control parameter that is the temperature and the humidity of the area. The inputs received by the temperature and humidity sensors give the closest output values for the air conditioning system. The simulation result shows temperature and humidity of the heat exchange by using defuzzification methods of centroid and middle of maxima $(\mathrm{MoM})$ in the Fuzzy Logic Toolbox of MATLAB package program.
\end{abstract}

Keywords: Fuzzy logic, defuzzification methods, air condition.

\section{Összefoglalás}

A tanulmány a légkondicionáló rendszer szabályzásánál alkalmazott két különböző defuzzációs módszert hasonlítja össze. A klímaberendezés müködése során két szabályozási paraméter, azaz a belső hőmérséklet és páratartalom szabályzása történik. A hőmérséklet és a páratartalom érzékelő által észlelt bemenetek a légkondicionáló rendszer kimeneti értékeit adják meg. A szimulációs eredmény a hőcserélő hőmérsékletét és páratartalmát mutatja a centroid és a Maximumok közepe (MoM) defuzzifikációs módszerek alkalmazásával MATLAB Fuzzy Logic Toolbox környezetben.

Kulcsszavak: Fuzzy logika, defuzzifikáció, légkondiciónálás.

\section{Bevezetés}

A fuzzy logika a matematika egy olyan ága, amely az emberi gondolkodáson alapul, azt matematikai függvényekké alakítja. A fuzzy logika legfontosabb tulajdonsága a fuzzy halmazelméleten alapuló matematikai diszciplína a bináris Arisztotelész logika (igen vagy nem, 1 vagy 0 stb.) helyett. A fuzzy logika értéket rendel a két bináris érték között: a rövid, a sok, a kevés, a normál, a közepes és a hosszú érték helyett 0-1 érték között közbenső értékeket (például: 0,6 - 0,1) használ.

A fuzzy logikát az azerbajdzsán L. A. Zadeh az 1960-as évek közepén írta le elöször matematikai tanulmányként. Ezt az elméletet olyan területeken alkalmazzák, ahol a matematikai kifejezéseket nehezen lehet elérni [1]. Az első fuzzy logikai vezér- 
lő alkalmazást a Mamdani 1974-ben hajtotta végre egy gőzgép vezérlésével. Mamdani azt igazolta, hogy Zadeh megközelítését a számítógép könnyen tudja kezelni [2].

Azt a folyamatot, amikor a fuzzy kimenetet éles értékre konvertáljuk, nevezzük defuzzifikációnak. A defuzzifikációs folyamat a légkondicionáló rendszer fuzzy szabálybázisú szabályzásának utolsó lépése. A fuzzy szabály a feldolgozó egységben kap szabályértékeket az optimalizálóban értékeljük és egy meghatározott éles eredményre konvertáljuk.

Tanulmányunkban a klímatechnikai modellezést megvizsgáljuk a fuzzy logikai vezérlőrendszerek alapelvei szerint, két különböző módszert bemutatva. Nagy jelentőséggel bír az idődomainrendszerben lévő kis hőmérséklet-változások vizsgálata, amelyek folyamatosan befolyásolják a rendszer kimenetét a fuzzy logikai vezérlési rendszerrel.

\section{Fuzzy tudásbázisú szabályzás}

A fuzzy tudás alapú (Fuzzy Knowledge Based - FKBC) szabályozás az elmúlt években széles körben alkalmazott szabályozási algoritmus kifejlesztésének egyik módja. Nem célszerủ hagyományos szabályozási módszereket alkalmazni, különösen összetett rendszerekben. E módszerek alkalmazása ilyen helyzetekben drága és meglehetősen nehézkes. Ebből a szempontból a bonyolult rendszereket könnyen lehet fuzzy logikával modellezni. Számos összetett alkalmazásban sok tudományos tanulmány és alkalmazás nagy teljesítményt ért el fuzzy logikával. Azonban a fuzzy logika közvetlenül kapcsolódik a tapasztalathoz is. A helyes szabálybázisok azonosítása biztosítja, hogy a tényleges eredményekhez legközelebb eső eredmények a tapasztalatoktól függően érhetők el. Ez a tapasztalat sok időt vehet igénybe az alkalmazástól függően, amit a fuzzy logika hátrányának kell tekintenünk.
Az FKBC fö tervezési paraméterei skálázási tényezők, fuzzifikáció, szabálybázis és defuzzifikációs módszerek stb.

\section{Légkondicionáló fuzzy szabályo- zása}

Légkondicionáló rendszer tipikus példája a nagyméretủ szabályozásnak.

Mivel a hőmérséklet és páratartalom szabályozása paraméterek kölcsönhatásban vannak egymással. Ez azt jelenti, hogy a szobahőmérséklet automatikusan megváltozik, ha a páratartalom változik, még akkor is, ha az a kívánt érték. A szabályozók hömérsékletének és relatív páratartalmának RH (\%) meg kell egyezzen.

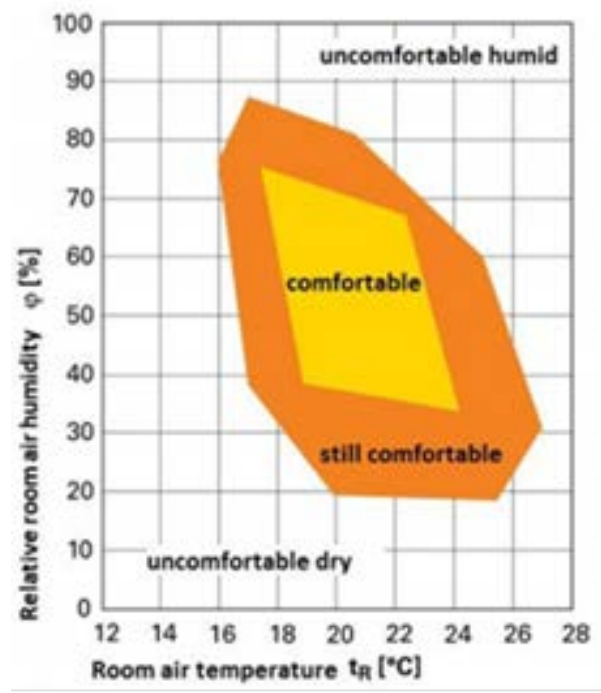

1. ábra. A komfortzóna területe a hömérséklet és a páratartalom függvényében (forrás: [3])

A légkondicionáló rendszer célja a hőmérséklet és a páratartalom együttes szabályozása. A szobahömérséklet 18 és $24^{\circ} \mathrm{C}$ között legyen, a páratartalom függvényében. Az optimális relatív páratartalom 35 és $70 \%$ között van. Általában a belső hőmérséklet szabályozásával érhető el. Ezenkívül az emberek magasabb hőmérsékletet érzik 
magukat a magasabb páratartalom mellett az alacsonyabb páratartalom szemben.

A fuzzy logika a légkondicionáló rendszer egy kedvezö megközelítése. A beállítások nagysága gyakorlatilag összeegyeztethetetlen, a nyelvi fogalomba át lehet alakítani a közvetlen koncepciót. Mert az emberek nem ragaszkodnak meghatározott hömérséklethez, illetve páratartalomhoz. Ezzel ellentétben az ember nagy kényelmet élvez. Ennek következtében ez a kényelmes zóna annak a személynek az érzete, aki nyugalomban van egy olyan helyiségben, ahol a hőmérséklet alacsony és a páratartalom kissé magasabb.

A müködési elv ugyanaz, mint egy forró és hideg oldalú levegő / levegő hőszivattyú esetében. Miközben a hőt belülről kifelé áramoltatják, kompresszor és két ventilátor müködtetése mellett áramot használnak. A szállítóközeg a hütőközeg, amely szobahömérséklet alatti hőmérsékleten a beltéri egységben elpárolog. Hőenergia szükséges a hütőközeg elpárologtatásához, amíg a párologtató belsejében lévő összes folyadék gőzbe nem vált. A kompresszor emeli a nyomást, és vele együtt a párolgott hütőközeg hömérséklete magasabb, mint a környezeti hömérséklet. Ezen a ponton a tárolt hö automatikusan visszautasítható kívülröl, mivel a hűtőközeget folyadékba kondenzálják. A tágulási szelep kioldja a nyomást és ezzel együtt a beltéri egység hőmérsékletét a kiindulási pont felé. A ventilátorok mindkét oldalon támogatják a hỏátadást. Ennek a ciklusnak az az elönye, hogy több hűtőkapacitást lehet biztosítani, amennyire szükséges.

\section{Esettanulmány}

A fuzzifikáció a bemeneti változók és a kimeneti változók nyelvi kifejezésekké történő átalakításának folyamata. Ezért a kezdeti bemeneti és kimeneti változókat bemenő változóként határozzák meg a légkondicionáló rendszer számára; belső hőmérsék- let esetén a hőmérséklet és a páratartalom hatását választották ki, és kimeneti változóként; Fütő és párásító. A nyelvi kifejezések meghatározása a bemeneti és a kimeneti változó tagság mértékével történik. A kimeneti változók tagsági fokozatai a szabályok súlyai szerint is módosulnak. Jelen tanulmányunkban a centroid és a maximális középérték módszerét alkalmazzuk.

Lehetőség van arra is, hogy a rendszer érzékenyebbé váljon a belső hőmérséklet és más változók meghatározott nyelvi kifejezései által érintett területek csökkentésével vagy új minősítőkkel. Az alternatívák itt attól függnek, hogy az adott személy mit választ.

A fuzzifikációhoz használt nyelvi kifejezések, a belső hőmérséklet: hideg, normál és meleg. A tagsági függvények az adott személy belátása szerint kerülnek meghatározásra. Különböző értékek adhatók meg a terület használatának és a nyelvi kifejezések növelésének függvényében. Például, egy olyan rendszerhez különböző nyelvi minősítéseket és értékeket kell alkalmazni, amelyek csak az elektronikus eszközök hőmérsékletének szabályozására alkalmazhatók, különböző nyelvi minősítéseket és értékeket hozhatnak létre ahhoz, hogy egy rendszert emberi egészségre tervezzenek.

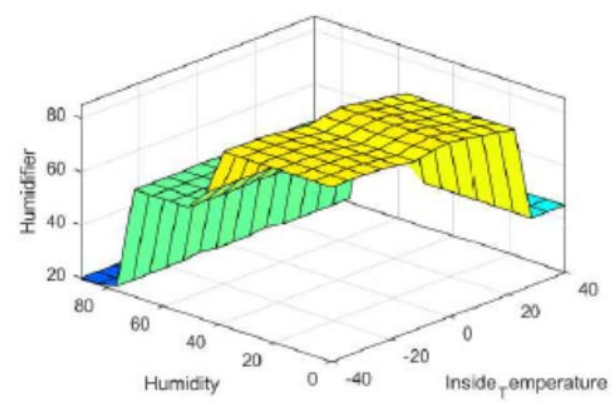

2. ábra. A párásító defuzzifikációs felülete MoM defuzzifikáció esetén

A szabályzó rendszerek kialakításában felmerülő főbb nehézség az, hogy nehéz és bonyolult az ellenőrzendő rendszer mate- 
matikai modelljének kialakítása. Megfigyelték, hogy a hőcserélő hőmérséklete és páratartalma ennek megfelelöen lágyabbnak bizonyult, és a kívánt páratartalom változtatásának mechanizmusa lehetővé tette számunkra, hogy gyorsabban haladjunk el.

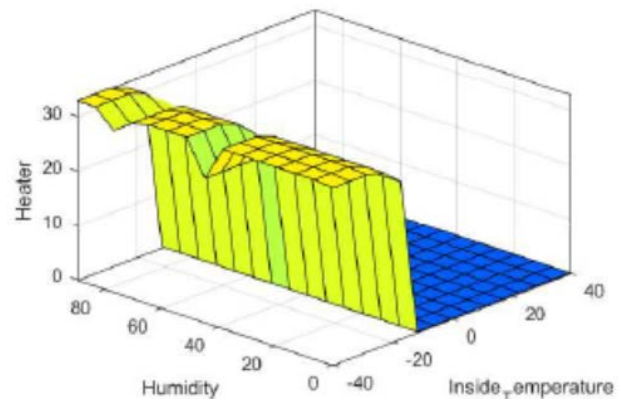

3. ábra. A höszabályzó defuzzifikációs felülete MoM defuzzifikáció esetén

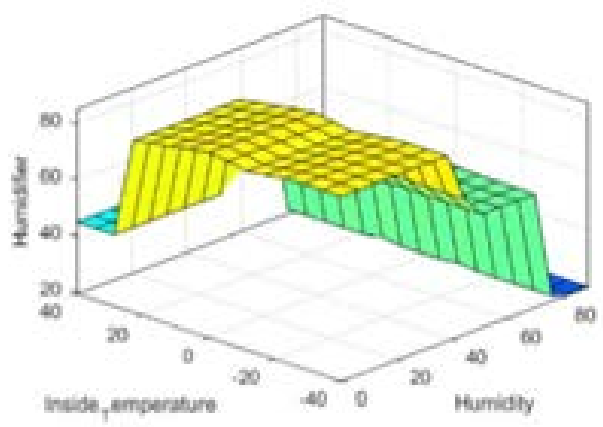

4. ábra A párásító defuzzifikációs felülete centroid defuzzifikáció esetén

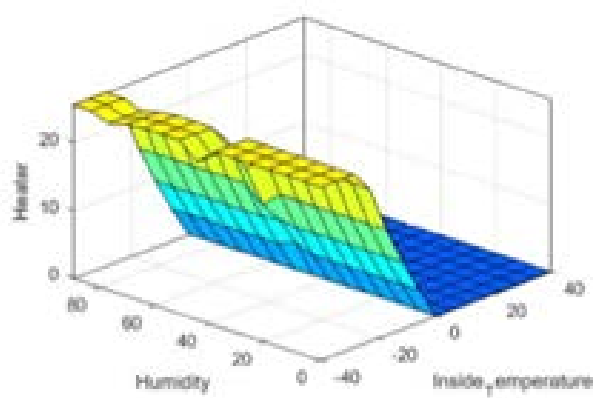

5. ábra A hőszabályzó defuzzifikációs felülete centroid defuzzifikáció esetén

\section{5. Összegzés}

Tanulmányunkban elvégeztük a légkondicionáló rendszer Fuzzy Logic elemzését, és a MATLAB csomagprogram Fuzzy Logic Toolbox szimulációját készítettünk a rendszerrel kapcsolatos eredmények elemzésére.

\section{References}

[1] Zadeh, L. A. (1996). Fuzzy sets. In Fuzzy Sets, Fuzzy Logic, And Fuzzy Systems: Selected Papers by Lotfi A Zadeh, 394-432.

[2] E. H. Mamdani, „Application of fuzzy algorithms for control of simple dynamic plan. Proceedings of the Institution of Electrical Engineers, 1974, 1585-1588.

[3] R. Kosonen és F. Tan: Assessment of productivity loss in air-conditioned buildings using PMV index. Energy and Buildings, 1. kötet 1. szám 10, 2004, 987-994. 